\title{
Local Wisdom of Farmers in Ngadas Village, Malang Regency in the Management of Agricultural Landscapes
}

\author{
Sri Utami ${ }^{1}$, Antariksa $^{2}$, Dian Kartika Santoso ${ }^{3 *}$ \\ ${ }^{1,2,3}$ Department of Architecture, Faculty of Engineering, Universitas Brawijaya, Malang, Indonesia. \\ *Corresponding author. Email: diankartikasantoso@gmail.com
}

\begin{abstract}
In Indonesia, Ngadas Village is one of the Agricultural Villages. Ngadas people do more activities in the fields than in their homes or dwellings. So, research about local wisdom of the Ngadas community in managing an agricultural landscape was fascinating. This research aimed to provide an overview of the initiative, creativity, work of the Ngadas community through artifacts in the agricultural landscape in Ngadas Village. The research was conducted through a qualitative approach. As a result, Tenggerese people have their way of survival. They are processing their crops by planting cover crops that function for animal feed. Nevertheless, ecologically, it has a significant impact on reducing erosion and eroding nutrients. Also, cover crops such as rumput gajah function as physical boundaries and form their field territory. Farmers in Ngadas also build farmhouses as a form of sustainable agriculture by making potato seeds from the harvest. Aside from being a potato seed storage, farmhouses are also a place to rest without leaving their cultural aspects, namely gegenen. Gegenen is an activity to make a body warms itself by burning charcoal when the weather is very cold. So it can be concluded that the local wisdom of the Ngadas community in managing their agricultural landscape is a form of adaptation from their environment.

Keywords: Local wisdom, agricultural landscape, culture, enclave village.
\end{abstract}

\section{INTRODUCTION}

Indonesia is an agricultural country, as seen from the people's livelihoods [1]. The livelihood system of Indonesian people, according to Boelaars [2], is divided into gatherers, field farmers, paddy farmers, and coastal people. The classification is different from Koentjaraningrat [3], which divides the livelihood system of a tribe into a community hunting and gathering, raising livestock, farming in the fields, catching fish, and farming with irrigation. From these two opinions, it can be concluded that the livelihoods of the Indonesian people are classified into hunter and gatherer communities, livestock, fishers, field farmers, and rice farmers [2,3].

The different livelihoods happen because of the influence of landscape conditions. Landscapes themselves are interpreted not only in the form of natural conditions but more broadly seen as a form of culture that includes human interaction, activities, and the environment [4,5]. Cultural systems are shaped by creativity, taste, and human work that is influenced by several natural environmental factors such as animals, plants, altitude, weather, and topography $[2,3,6]$. The development of culture from an entity or ethnicity is inseparable from how to obtain food. Livelihood is one of the cultural elements that function as a cultural identity of a society [3]. Specifically, the functioning of agrarian areas that produce food and contribute to socio-economic sustainability can be referred to as agricultural or agricultural landscapes $[7,8]$.
In Indonesia, Ngadas Village is one of the Agricultural Villages in Poncokusumo District, Malang Regency, East Java. Uniquely, the population in Ngadas Village is dominated by the Tengger Tribe [9-11]. The Tenggerese has a group living with each other characteristics and only $1 / 1000$ of the population of the island of Java $[12,13]$. Ngadas village stretches between 1200-2500 meters above sea level (masl) on the slopes of Mount Semeru [9,14-16]. Under these conditions, Ngadas is known as a vegetableproducing village $[9,13,14,16,17]$. Ngadas people do more activities in the fields than in their homes or dwellings [10, 11]. Communities build farmhouses called huts around the fields where they cultivated [10]. It is an interesting thing but has not been much explored by researchers. This research is expected to provide an overview of the initiative, creativity, work of the Ngadas community through artifacts in the agricultural landscape in Ngadas Village. Also, this research will complement the previous research on Ngadas Village.

\section{METHOD}

The research approach implemented uses a descriptive qualitative approach. The descriptive qualitative approach is expected to be able to provide a complete picture of the object of research and provide more detailed research results. Qualitative research is intended as a type of research whose findings are not obtained through statistical procedures or other forms of calculation $[18,19]$. Furthermore, qualitative research is chosen because the 
stability of researchers based on research experience and qualitative methods can provide more intricate details about phenomena that are difficult to express by quantitative methods [20]. In this study, descriptive qualitative analysis was used to describe the local wisdom found in Ngadas Village, Malang Regency, concerning its agricultural landscape management.

\section{RESULT AND DISCUSSION}

The discussion is conducted by describing the features or elements contained in the agricultural landscape including (1) Agricultural features formed by the type of agricultural land use and (2) Cultural features result from interactions between human activities and the environment, including agricultural-related structures (e.g., barns, hedging), road lanes and transmission lines and signs (boards or fences) $[7,21]$.

\subsection{Agricultural features}

In macro terms, land use in Ngadas Village has not changed much; land use in Ngadas Village is dominated by forests and agricultural land. Its territory is far from residential. The shelter is formed in groups, and the position of its agricultural landscape is outside the settlement [22]. Meso, the community initially used agricultural land with a shifting cultivation system. This system caused changes to the landscape. At present, the shifting system is no longer done; the illustration of land use in shifting cultivation can be seen in Figure 1.

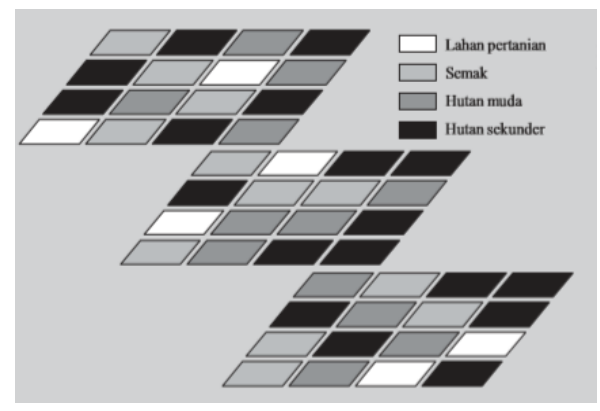

Figure 1 Illustration of land-use configurations in shifting cultivation systems

Agricultural land is in the middle of the forest and alternately used. Meso land use is only forest and agricultural land without any land being built. However, at present, agriculture is turning into permanent agriculture. There is a clear boundary between the forest and the zoning zone where land use is used for agricultural land, and the land is constructed in the form of houses (Figure 2).

Land use in the micro-agricultural landscape is agricultural land, built land, and roads. Domination remains on agricultural land. Since long ago, land that had steep slopes was planted using simple terraces by making water drainage channels. Relatively flat land is planted by making plots consisting of guludan, kalen, and galengan [23]. Galengan is a physical boundary that is usually planted by rumput gajah, paitan, or kolonjono (Figure 3). Galengan is a pathway in the middle of the field and facilitates the process of plant care.

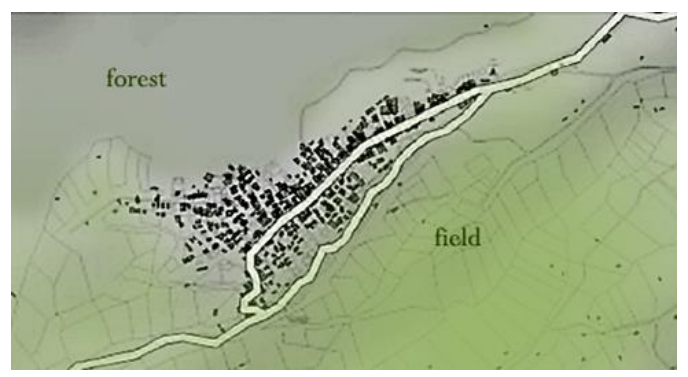

Figure 2 Illustration of secondary forest and separate fields

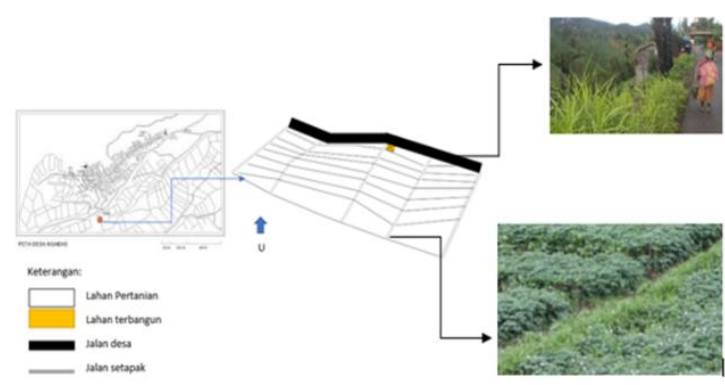

Figure 3 Rumput gajah as a physical boundary

Planting carried out by the Ngadas community following the lorong system. The lorong system is done by planting rumput gajah or other cover crops on the aisles between the planting areas as erosion inhibitors [24].

\subsection{Cultural Features}

Cultural features are the results of human cultural artifacts, one of which is in the form of houses [7,21]. Through indepth interviews and observations, it was found that the farmhouses in Ngadas Village were not originally housing with a permanent material, people used to call them sudung. Sudung only contains one space, which is a storage area for agricultural equipment and seeds. Based on the results of cognitive mapping in the community, sudung illustrations are shown in Figure 4.

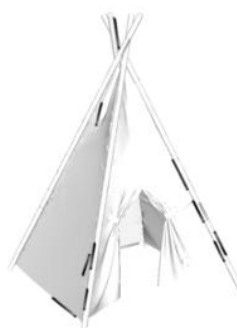

Figure 4 Illustration of Sudung 
Because there is only one room, there is no relationship between spaces. The location of sudung or fields is relatively flat land and is located in an affordable area from all corners of the field. Meanwhile, the existing farms (Figure 5) developed from the 1960s with material that continues to grow. If in the $90 \mathrm{~s}$ still using natural ingredients, now it has used other materials such as zinc, or brick on the walls.

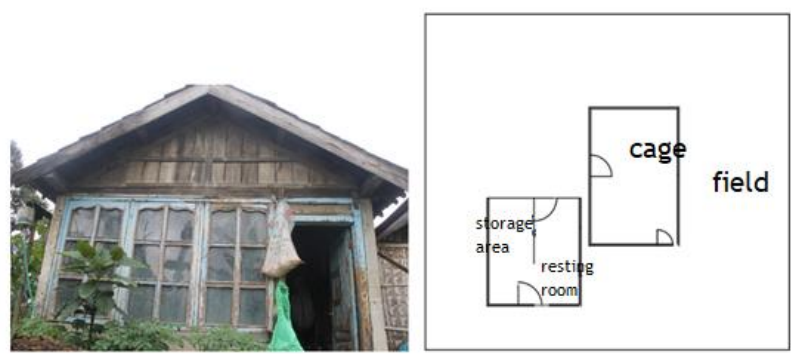

Figure 5 (a) Field house facade (b) Field house plan

Houses now have three space units, namely a place for storing agricultural tools and seeds, resting places, and pens. Storage space is used to store agricultural equipment and seeds (Figure 6).

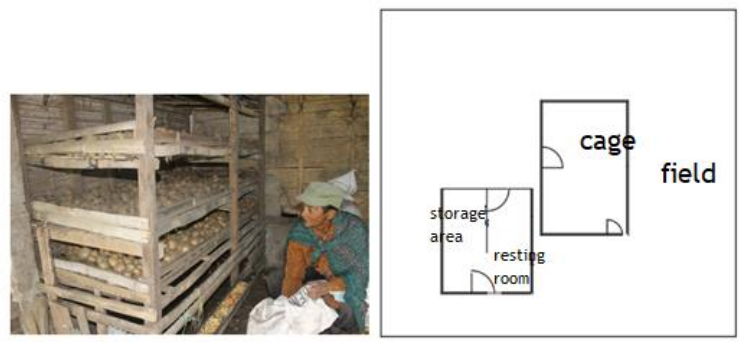

Figure 6 Storage area

The restroom is used for eating and drinking and gegenen activity during the rainy season (Figure 7). Gegenen is a Tenggerese culture as a form of adaptation to the cold temperatures of the mountains [25].

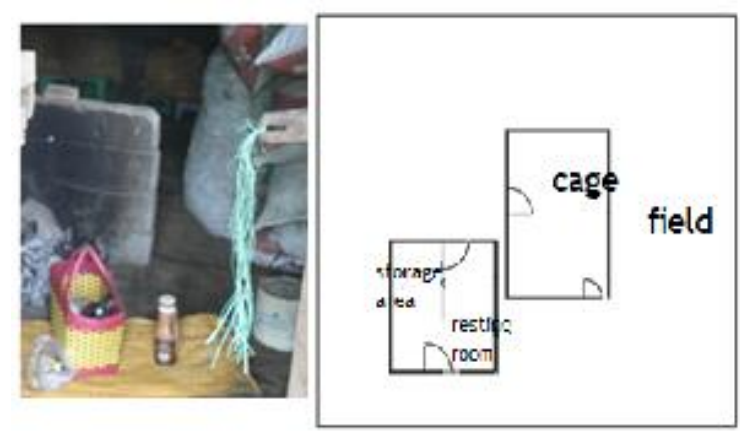

Figure 7 Resting place

Cages (Figure 8) are used to store livestock. There is two primary livestock raised in Ngadas, namely horses and pigs.

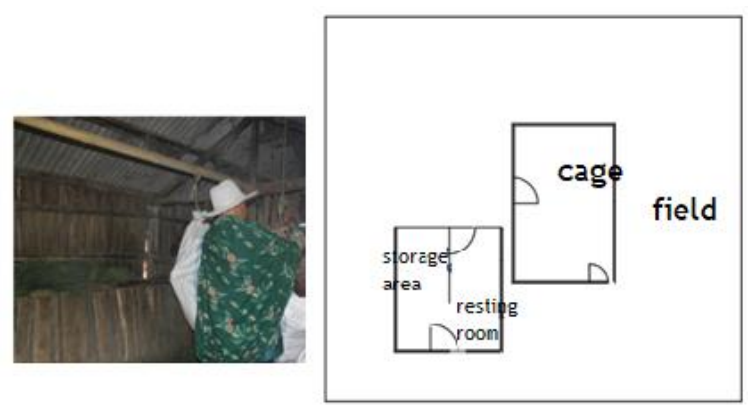

Figure 8 Horse stable

Every room in a farmhouse is an essential unit to support agricultural activities. Because of the importance of agriculture too, the farmhouse orientation farmhouse is always facing farm fields and is located in relatively flat areas.

\section{CONCLUSION}

Ngadas community has its way of survival. They process their crops by planting cover crops as a boundary that function for animal feed. However, ecologically, it has a significant impact on reducing erosion and eroding nutrients. Besides, cover crops such as elephant grass also function as physical boundaries and form their field territory. Farmers in Ngadas also build farmhouses as a form of sustainable agriculture by making potato seeds from the harvest. Aside from being a place for storing potato seeds, farmhouses are also used as a place to rest without leaving their cultural aspects, namely gegenen. Gegenen is an activity that warms itself by burning charcoal when the weather is very cold. It can be concluded that the local wisdom of the Ngadas community in managing their agricultural landscape is a form of adaptation from their environment.

\section{REFERENCES}

[1] A. M. Rijal, Antariksa, Arsitektur Masyarakat Agraris dan Perkembangannya. Malang: UB Press, 2019.

[2] Y. Boelaars, Kepribadian Indonesia Modern: Suatu Penelitian Antropologi Budaya. Jakarta: PT Gramedia, 1984.

[3] Koentjaraningrat, Pengantar Ilmu Antropologi. Jakarta: PT. Rineka Cipta, 2015.

[4] D. Sheil, R. K. Puri, I. Basuki, M. v. Heist, M. Wan, N. Liswanti, et al., Exploring biological diversity, environment and local people's perspectives in forest landscapes: Methods for a multidisciplinary landscape assessment, Second edition ed. Bogor: CIFOR, 2003. 
[5] A. S. Riyani, Antariksa, and J. Ernawati, Sistem Organisasi Keruangan Pada Lansekap Tradisional Hindu-Kejawen di Dusun Djamuran, Kecamatan Wagir Malang, Jurnal Perspektif Arsitektur, vol. 9 (2014).

[6] W. Handoko and M. A. Mujabuddawat, Lingkungan Dan Lanskap Situs Kampung Tua Kao: Faktor Determinasi Permukiman dan Pusat Islamisasi di Halmahera Utara, KALPATARU, vol. 26 (2017) pp. 123-136,

[7] J. Gao, C. Barbieri, and C. Valdivia, Agricultural Landscape Preferences, Journal of Travel Research, vol. 53 (2013) pp. 366-379.

[8] J. Wang, Y. Hu, L. Sun, Z. Wang, K. Yu, L. Qiu, et al., Dynamic analysis of agricultural landscape pattern changes in Jiangsu, presented at the 6th International Conference on Agro-Geoinformatics, Fairfax VA, USA, 2017

[9] H. R. Agustapraja, Penerapan Genius Loci Pada Pemukiman Masyarakat Ngadas Tengger Malang, Jurnal CIVILLa, vol. 2 (2017).

[10] J. Batoro, Keajaiban Bromo Tengger Semeru. Malang: UB Press, 2017.

[11] BBTNBTS, Hikayat Wong Tengger: Kisah Peminggiran dan Dominasi: Balai Besar Taman Nasional Tengger Semeru, 2013.

[12] A. Sutarto, Sekilas Tentang Masyarakat Tengger, presented at the Jelajah Budaya, Yogyakarta, 2006.

[13] J. Batoro, D. Setiadi, T. Chikmawati, and Y. Purwanto, Pemanfaatan Tumbuhan Dan Hewan Dalam Ritual Adat Masyarakat Tengger di Bromo Tengger Semeru Jawa Timur, Jurnal Ilmu Ilmu Sosial, vol. 03 (2011).

[14] M. C. Endarwati, Pengaruh Mitos Pada Bentukan Ruang Bermukim Di Desa Ngadas Kecamatan Poncokusumo Kabupaten Malang, Jurnal Tesa Arsitektur, vol. 11 (2013).

[15] S. Budiyanti, Analisis Deskriptif Aktivitas Dan Potensi Komunitas Desa 'Enclave' Ranu Pane Pada Zona Pemanfaatan Tradisional, Kecamatan Senduro, Kab. Lumajang, Wilayah Taman Nasional Bromo Tengger Semeru (TNBTS), Jurnal DIMENSI, vol. 8 (2015).

[16] V. Anggiana and Bergas, Pembangunan Pariwisata dan Perampasan Ruang Hidup Rakyat: KSPN Menjawab Masalahnya Siapa?, Balai Taman Nasional Bromo Tengger Semeru, 2014.
[17] A. Listiyana and R. Mutiah, Pemberdayaan Masyarakat Suku Tengger Ngadas Poncokusumo Kabupaten Malang Dalam Mengembangkan Potensi Tumbuhan Obat Dan Hasil Pertanian Berbasis "Etnofarmasi" Menuju Terciptanya Desa Mandiri, Journal of Islamic Medicine, vol. 1 (2017) p. 1.

[18] L. N. Groat and D. Wang, Architectural research methods, Second Edition ed. Canada: John Wiley \& Sons, Inc, 2013.

[19] J. W. Creswell, Research design: qualitative, quantitative, and mixed methods approaches, 4 ed. New Delhi: SAGE Publications 2014.

[20] Sugiyono, Metode Penelitian Kuantitatif,Kualitatif, dan R\&D. Bandung: Alfabeta, 2016.

[21] E. Pouta, I. Grammatikopoulou, T. Hurme, K. Soini, and M. Uusitalo, Assessing the Quality of Agricultural Landscape Change with Multiple Dimensions, Land, vol. 3 (2014) pp. 598-616.

[22] S. Wiriaatmadja, Pokok-Pokok Sosiologi Pedesaan. Jakarta: Yasaguna, 1981.

[23] Y. Yuliati, Perubahan Ekologis dan Strategi Adaptasi Masyarakat di Wilayah Pegunungan Tengger. Malang: niversitas Brawijaya Press, 2011.

[24] N. T. Tjatjo, M. Basir, and H. Umar, Karakteristik Pola Agroforestri Masyarakat Di Sekitar Hutan Desa Namo Kecamatan Kulawi Kabupaten Sigi, Jurnal Sains dan Teknologi Tadulako, , vol. 4 (2015) pp. 55-64.

[25] D. Pancawati and A. Ami, Segmentation of Hearth (Pawon) Space In Tenggerese House, Archnet-IJAR, vol. 9 (2015). 